\title{
Study of 16 Portuguese activated sludge systems based on filamentous bacteria populations and their relationships with environmental parameters
}

\author{
Liliana Araújo dos Santos • Vânia Ferreira • \\ Marta Martins Neto • Maria Alcina Pereira • \\ Manuel Mota $\cdot$ Ana Nicolau
}

Received: 18 July 2014 / Revised: 6 January 2015 / Accepted: 8 January 2015 / Published online: 11 February 2015

(C) Springer-Verlag Berlin Heidelberg 2015

\begin{abstract}
A survey in 16 activated sludge wastewater treatment plants (WWTP) was conducted to contribute to the knowledge of the environmental parameters that determine the composition of the filamentous community. A total of 128 samples of mixed liquor from municipal WWTP were collected during 2 years, and 22 filamentous morphotypes were identified. The most frequent and abundant filamentous bacteria were, in both cases and by this order, type 0041/0675, type 0092, Microthrix parvicella and 1851, nocardioforms and Haliscomenobacter hydrossis. Concerning dominance, type 1851 was the most frequently dominant morphotype, followed by M. parvicella and types 0092 and $0041 / 0675$. These were also, and by this order, the dominant morphotypes during bulking occurrences. Significant correlations were obtained between the abundance of filamentous bacteria and environmental parameters, but multivariate statistical analysis only confirmed the correlation between type 0092 and Sludge Volume Index (SVI), emphasizing the association of this filament with bulking. The discussion of the results in light of published works was complicated by the random use of terms such as frequency, abundance, and dominance with different and often unclear meanings. This reinforces the need of clarifying these terms when discussing the causes of filamentous overgrowth in WWTP.
\end{abstract}

Keywords Activated sludge · Filamentous bacteria . Environmental parameters $\cdot$ Correlations $\cdot$ PCA

L. Araújo dos Santos $\cdot$ V. Ferreira • M. M. Neto $\cdot$ M. A. Pereira $\cdot$ M. Mota $\cdot$ A. Nicolau $(\bowtie)$

CEB-Centro de Engenharia Biológica, Universidade do Minho, Campus de Gualtar, 4710-57 Braga, Portugal

e-mail: protozoa@deb.uminho.pt

\section{Introduction}

Activated sludge process is the most common technology for treating several types of wastewater, such as domestic sewage and industrial effluents. The diversity of the biological community inhabiting the aerating tank of these plants is amply large, containing many species of viruses, bacteria, protozoa, fungi, little metazoa, and even algae. In this complex ecosystem, bacteria represent approximately $95 \%$ of the total microbial population biomass (Jenkins et al. 2004). Bacteria in activated sludge can be divided into floc-forming and non-flocforming forms, being the latter mostly filamentous bacteria. Bacteria that are kept in the activated sludge process under the correct environmental conditions, that is, with sufficient oxygen and balanced food, can efficiently remove the organic material and nutrients from wastewater effluent (Martins et al. 2004). On the other hand, a good separation (settling) and compaction (thickening) of activated sludge in the secondary clarifier is a necessary condition to guarantee a good effluent quality (Martins et al. 2004).

Some problems associated with the activated sludge technology - the development of a thick viscous scum or foam on the surface of activated sludge aeration tanks and clarifiers (known as foaming) and the inadequate solid separation (or bulking) - are usually connected with an unbalanced growth of filamentous microorganisms. Serious problems of filamentous bulking and foaming are worldwide known and lead to poor treatment quality. Eikelboom (1975) developed the first identification key to identify filamentous bacteria in activated sludge systems, mainly based on morphological 
characteristics and on the response of the filamentous bacteria to a few microscopic staining tests. Reference manuals were published with the description and characterization of 25 different filamentous bacteria commonly found in activated sludge (Eikelboom 1975, 2000; Jenkins et al. 2004). Meanwhile, some publications discussed in detail the reasons for the excessive proliferation of filamentous bacteria (Eikelboom 2000; Jenkins et al. 2004; Tandoi et al. 2006; Nielsen et al. 2009; Seviour and Nielsen 2010).

Conventional microscopic sludge analysis is and will be an essential monitoring instrument for the technicians, as it provides information about sludge quality and operation conditions besides detection of filamentous bacteria (Müller et al. 2007). On the other hand, the difficult and ambiguous identification of filamentous bacteria by conventional microscopic techniques led to molecular methods based on analyzing DNA or RNA of the bacteria (Seviour and Nielsen 2010). Fluorescence in situ hybridization (FISH) with DNA probes which employ fluorescently labeled rRNA-targeted oligonucleotides is used to confirm identifications, to localize specific organisms, and to give more detailed information on the various taxonomic levels.

The aim of the present work is to establish the environmental parameters that determine the composition of the filamentous community in activated sludge. For that, a set of 16 activated sludge plants were followed during 2 years and the relationships between the physicalchemical and operational parameters and the filamentous organisms were inspected through statistical analysis.

\section{Materials and methods}

Description of the wastewater treatment systems

The study was performed in 16 activated sludge wastewater treatment plants (WWTP), located in the north of Portugal (region of Minho) with nutrients removal. These WWTP are considered urban WWTP: they receive domestic and industrial sewage in different amounts, and even in the case of relatively high amounts of industrial residual water, this is not quantitatively or qualitatively defined and varies along time.

Sampling and preservation

Mixed liquor samples were collected from the aeration tank every 3 months, during 2 years, in a total of 128 samples. The samples were sent by express mail and arrived at maximum $5 \mathrm{~h}$ after collection. Once in the laboratory, they were microscopically examined and stored at $4{ }^{\circ} \mathrm{C}$ for further confirmation if necessary. Gram and Neisser smears were also made.

Samples were fixed prior to hybridization. They were preserved in paraformaldehyde and ethanol for the analysis of gram-negative cells and in ethanol for the examination of gram-positive cells, and then stored at $-20{ }^{\circ} \mathrm{C}$.

\section{Environmental parameters}

Environmental variables were determined according to the Standard Methods (APHA/AWWA/WEF 1995): biological oxygen demand in 5 days $\left(\mathrm{BOD}_{5}\right)$, chemical oxygen demand (COD), total suspended solids (TSS), $\mathrm{pH}$, total nitrogen (TN), ammonium nitrogen $\left(\mathrm{NH}_{4}-\mathrm{N}\right)$ and total phosphorus (TP) from affluent and effluent, nitrate nitrogen $\left(\mathrm{NO}_{3}-\mathrm{N}\right)$ from effluent and sludge retention time (SRT), sludge volume index (SVI), food to microorganism (F/M), dissolved oxygen (DO), TSS, and $\mathrm{pH}$ from aeration tank. Minimum, maximum, mean values, and standard deviation of each parameter during the period of study are shown in Table 1 .

Table 1 Environmental parameters in the WWTP during the period of study

\begin{tabular}{|c|c|c|c|c|}
\hline & Minimum & Maximum & Average & SD \\
\hline \multicolumn{5}{|l|}{ Affluent } \\
\hline $\mathrm{pH}$ & 6.18 & 9.00 & 7.42 & 0.5 \\
\hline COD (mg/l) & 12.8 & 4540 & 588.75 & 463.9 \\
\hline BOD (mg/l) & 22 & 1000 & 308.21 & 204.6 \\
\hline TSS (mg/l) & 30 & 1240 & 267.52 & 185.7 \\
\hline $\mathrm{TP}(\mathrm{mg} / \mathrm{l})$ & 1 & 185 & 33.79 & 44.9 \\
\hline $\mathrm{TN}(\mathrm{mg} / \mathrm{l})$ & 12 & 355 & 97.64 & 54.5 \\
\hline $\mathrm{NH}_{4}-\mathrm{N}(\mathrm{mg} / \mathrm{l})$ & 2 & 230 & 65.71 & 56.4 \\
\hline \multicolumn{5}{|l|}{ Areation tank } \\
\hline $\mathrm{pH}$ & 6.05 & 8.39 & 6.95 & 0.38 \\
\hline $\mathrm{SVI}(\mathrm{ml} / \mathrm{g})$ & 36.23 & 403.23 & 212.15 & 82.86 \\
\hline SRT (days) & 0 & 334.1 & 25.79 & 39.74 \\
\hline $\begin{array}{l}\mathrm{F} / \mathrm{M}\left(\mathrm{kg} \mathrm{BOD} \mathrm{BD}_{5} / \mathrm{kg}\right. \\
\text { VSS.d) }\end{array}$ & 0.01 & 0.77 & 0.09 & 0.1 \\
\hline DO (mg/l) & 0.17 & 5.19 & 1.41 & 0.76 \\
\hline TSS (mg/l) & 1825 & 7815 & 3341.45 & 879.14 \\
\hline \multicolumn{5}{|l|}{ Effluent } \\
\hline $\mathrm{pH}$ & 5.88 & 8.51 & 7.04 & 0.41 \\
\hline $\mathrm{COD}(\mathrm{mg} / \mathrm{l})$ & 3 & 93 & 35.26 & 20.6 \\
\hline BOD (mg/l) & 1 & 26 & 7.39 & 5.25 \\
\hline TSS (mg/l) & 0.5 & 48 & 9.28 & 8.47 \\
\hline $\mathrm{TP}(\mathrm{mg} / \mathrm{l})$ & 0.3 & 70 & 5.7 & 9.8 \\
\hline $\mathrm{TN}(\mathrm{mg} / \mathrm{l})$ & 3 & 140 & 28.49 & 23.79 \\
\hline $\mathrm{NH}_{4}-\mathrm{N}(\mathrm{mg} / \mathrm{l})$ & 0.1 & 101 & 14.1 & 19.78 \\
\hline $\mathrm{NO}_{3}-\mathrm{N}(\mathrm{mg} / \mathrm{l})$ & 0.2 & 60 & 9.08 & 12.41 \\
\hline
\end{tabular}


Identification of the filamentous bacteria

\section{Conventional microscopy}

Activated sludge wet mounts and smears were prepared for examination of filamentous bacteria. To determine morphological characteristics of the various filamentous, wet mounts were inspected under bright field and phase contrast at $\times 1000$ magnification. Smears were stained according to Gram and Neisser staining techniques and examined under oil immersion and bright field also at $\times 1000$ magnification. The test $\mathrm{S}$ (sulfide oxidation) was applied to determine the presence/ absence in situ of intracellular sulfur deposits to confirm the identifications of Thiothrix spp. and type $021 \mathrm{~N}$. The microscopic observations of filamentous bacteria and its morphologic features were performed using an OLYMPUS CX41 microscope. Morphological identification of filamentous bacteria was done by comparing the observed filament with the various characteristics outlined by referenced manuals (Eikelboom 2000; Jenkins et al. 2004).

\section{Fluorescence in situ hybridization}

FISH was performed according to the protocol of Nielsen et al. (2009) to confirm the identifications of some filamentous bacteria. The fixed samples were dehydrated in 50,80 , and $96 \%(v / v)$ ethanol. After $2-3 \mathrm{~h}$ of hybridization at $46{ }^{\circ} \mathrm{C}$, the samples were washed in a buffer and incubated for $10-15 \mathrm{~min}$ at $48{ }^{\circ} \mathrm{C}$. Lysozyme and
Achromopeptidase solutions were used to permeabilize gram-positive cells at $37{ }^{\circ} \mathrm{C}$ for $10-20 \mathrm{~min}$. The probes were used to confirm identifications or to clarify certain morphotypes (Table 2), and the hybridization conditions applied (different formamide concentrations) were those detailed in their original publications. The probes were fluorescently tagged with ALEXA488, Fluorescein, or CY3 fluorochromes. NONEUB338 probes labeled with ALEXA488, Fluorescein, and CY3 were used to confirm if non-specific binding occurred or if the fluorochrome adsorbed to the biomass. DAPI (4,6-diamidino-2phenylindole) staining was applied to visualize the morphology and distribution of filamentous bacteria within the biomass. The microscopic observations of filamentous bacteria were performed using an OLYMPUS BX51 fluorescence microscope.

For some of the morphotypes, probes are not available (e.g., types 0961 and 0411) or clearly validated (e.g., types 0803 and 0914). In what Thiothrix identification concerns, two categories were considered. During FISH, some of the filaments previously identified as Thiothrix showed a negative response to the specific probe for Thiothrix spp. (G123T probe). The positive filaments were then termed "Thiothrix spp.". The other filaments had particular characteristics similar to the previously described Thiothrix spp. but showed a negative response to test $\mathrm{S}$ and a positive response to the Chloroflexi group probe: they were referred "Thiothrixsimilar morphotype" in this study.

Table 2 FISH probes

\begin{tabular}{|c|c|c|c|}
\hline Probe & Morfotype & Sequence & Source \\
\hline EUB338 I $b$ & All Bacteria & GCTGCCTCCCGTAGGAGT & Amann et al. (1990) \\
\hline EUB338 II $b$ & Planctomycetales & GCAGCCACCCGTAGGTGT & Daims et al. (1999) \\
\hline EUB338 III $b$ & Verrucomicrobiales & GCTGCCACCCGTAGGTGT & Daims et al. (1999) \\
\hline CHL1851 & $\begin{array}{l}\text { Type } 1851 \text { filamentous } \\
\text { bacteria }\end{array}$ & AATTCCACAACCTCTCCA & Beer et al. (2002) \\
\hline $\mathrm{G} 123 \mathrm{~T}+\mathrm{G} 123 \mathrm{~T}-\mathrm{C}$ & Thiothrix spp. & $\begin{array}{l}\text { CCTTCCGATCTCTATGCA+CCTTCC } \\
\text { GATCTCTACGCA }\end{array}$ & Kanagawa et al. (2000) \\
\hline SNA & Sphaerotilus natans & CATCCCCCTCTACCGTAC & Wagner et al. (1994) \\
\hline HHY & Haliscomenobacter hydrossis & GCCTACCTCAACCTGATT & Wagner et al. (1994) \\
\hline $\begin{array}{l}\text { MPAmix (MPA60+MP223 } \\
\text { +MPA645)A }\end{array}$ & Microthrix parvicella & $\begin{array}{l}\text { GGATGGCCGCGTTCGACT } \\
\text { GCCGCGAGACCCTCCTAG } \\
\text { CCGGACTCTAGTCAGAGC }\end{array}$ & Erhart et al. (1997) \\
\hline Myc657 & Nocardioform (GALO/PTLO) & AGTCTCCCCTGYAGTA & Davenport et al. (2000) \\
\hline NONEUB & $\begin{array}{l}\text { Control probe complementary } \\
\text { to EUB338 }\end{array}$ & ACT CCT ACG GGA GGC AGC & Wallner et al. (1993) \\
\hline $\begin{array}{l}\text { CFXMIX (GNBSB941 } \\
\quad+\text { CFX1223) }\end{array}$ & Phylum Chloroflexi & $\begin{array}{l}\text { AAACCACACGCTCCGCT+CCATTG } \\
\text { TAGCGTGTGTGTMG }\end{array}$ & $\begin{array}{l}\text { Bjornsson et al. (2002); } \\
\text { Gich et al. (2001) }\end{array}$ \\
\hline $\begin{array}{l}\text { CF223+CFX197-C } \\
\quad+\text { CFX223 }\end{array}$ & Type 0092 filamentous bacteria & $\begin{array}{l}\text { TCCCGGAGCGCCTGAACT+TCCCGAAG } \\
\text { CGCCTGAACT+GGTGCTGGCTCCTCCCAG }\end{array}$ & Speirs et al. (2009) \\
\hline
\end{tabular}

$b$ EUB338 I, II, and III used in equimolar amounts as EUBmix 


\section{Quantification of filamentous bacteria}

Frequency is the number of times that each filamentous morphotype appears in the total set of samples. It is presented as a percentage of the occurrence in the 128 samples.

Filamentous microorganisms were quantified according to a subjective scoring of filament abundance $(0=$ none, $1=$ few, $2=$ some, $3=$ common, $4=$ very common, $5=$ abundant, and $6=$ excessive) adapted from Jenkins et al. (2004). Abundance is weighed, corresponding to the sum of the products of the frequencies and the respective scores of abundance from 0 to 6. It is presented as a percentage of each weighed abundance in the sum of the weighed abundances of all morphotypes.

The dominance corresponds to the number of times that a morphotype appears in scores of 5 and/or 6 . It is also presented as a percentage.

\section{Data analysis}

In order to try to understand the relationships between the filamentous bacteria and the environmental parameters, correlations analyses were performed. These correlations were made using the most frequent morphotypes and only 78 samples were selected since the other had missing data on environmental parameters (data not supplied by the WWTP).

Data statistical analysis was performed by Kendall: correlation coefficients and factor analysis (factor extraction method: principal components, transformation method: Varimax), using programs in the STATISTICA 7.0.

Twelve environmental parameters of effluent quality were selected for data analysis: $\mathrm{BOD}_{5}, \mathrm{COD}, \mathrm{TSS}, \mathrm{pH}, \mathrm{TN}, \mathrm{NH}_{4}-$ $\mathrm{N}, \mathrm{NO}_{3}-\mathrm{N}$, and TP from the effluent and SRT, SVI, F/M, DO, TSS, VSS, and $\mathrm{pH}$ from the aeration tank. Correlation coefficients were determined in order to examine potential relationships between the filamentous bacteria and quality of effluent. All the values were normalized according to the logarithmic transformation, $x=\ln (x+1)$.

\section{Results}

The frequency, abundance, and dominance of the filamentous bacteria in activated sludge of the 16 WWTP during the sampling period are showed in Figs. 1 and 2 and Table 3, respectively. Twenty-two filamentous morphotypes were identified. Only the filamentous bacteria appearing in at least $50 \%$ of the samples in terms of frequency are discussed. The most frequent filamentous morphotypes appearing in at least $50 \%$ of the samples were, by this order, type 0041/0675, type 0092, Microthrix parvicella, type 1851, nocardioforms, and Haliscomenobacter hydrossis. The most frequent filamentous bacteria were also the most abundant, being the tendencies of both variables very similar: the only difference being the change in rank of $M$. parvicella and type 1851. On the other hand, the most frequent and abundant were not the most dominant in the studied WWTP. Type 1851 was clearly the most dominant (appearing with abundance indexes of 5 and 6 in $13 \%$ of the samples), followed by $M$. parvicella (10\%) and types 0092 and $0041 / 0675$ (9\%). These were also the most dominant filamentous bacteria in WWTP suffering bulking (SVI $\geq 150 \mathrm{~mL} / \mathrm{g}$ ) as shown in Table 4 .

Results of the correlation analysis between the filamentous bacteria and the environmental parameters are presented in Table 5.

Significant correlations between most of the filamentous morphotypes and several environmental parameters were obtained, but none for type 0041/0675. Nocardioforms showed

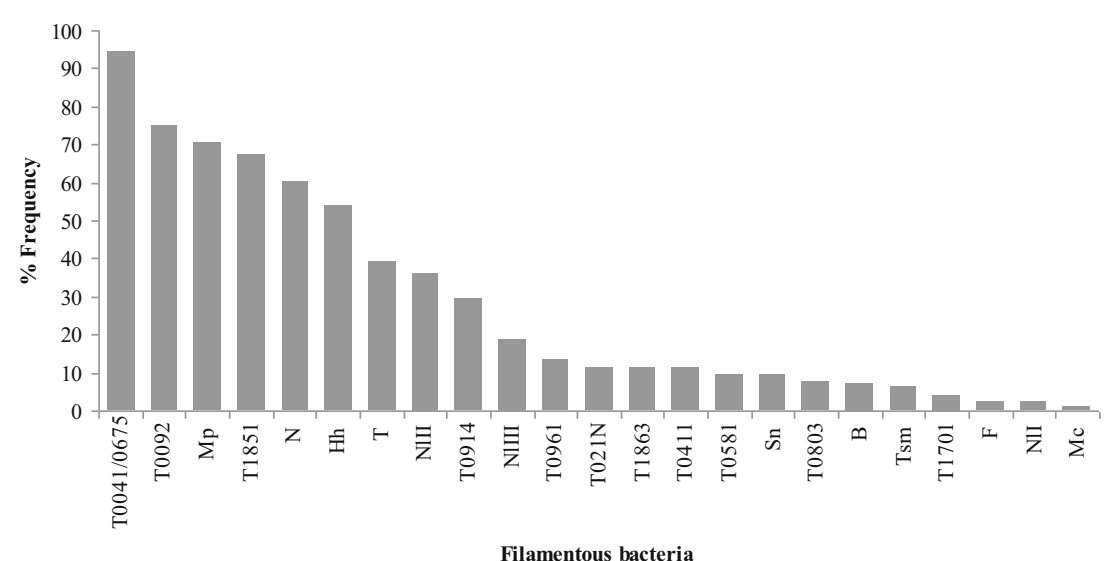

Fig. 1 Frequency of filamentous bacteria in the studied WWTP. Type 0041/0675 (T0041/0675); type 0092 (T0092); Microthrix parvicella (Mp); type 1851 (T1851); nocardioforms (N); Haliscomenobacter hydrossis (Hh); Thiothrix spp. (T); Nostocoida limicola II (N1II); type 0914 (T0914); Nostocoida limicola III (NIIII); type 0961 (T0961); type
$021 \mathrm{~N}$ (T021N); type 1863 (T1863); type 0411 (T0411); type 0581 (T0581); Sphaerotilus natans (Sn); type 0803 (T0803); Beggiatoa spp. (B); Thiothrix-similar morphology (Tsm); type 1701 (T1701); Flexibacter (F); Nostocoida limicola I (NII); Microthrix calida (Mc) 


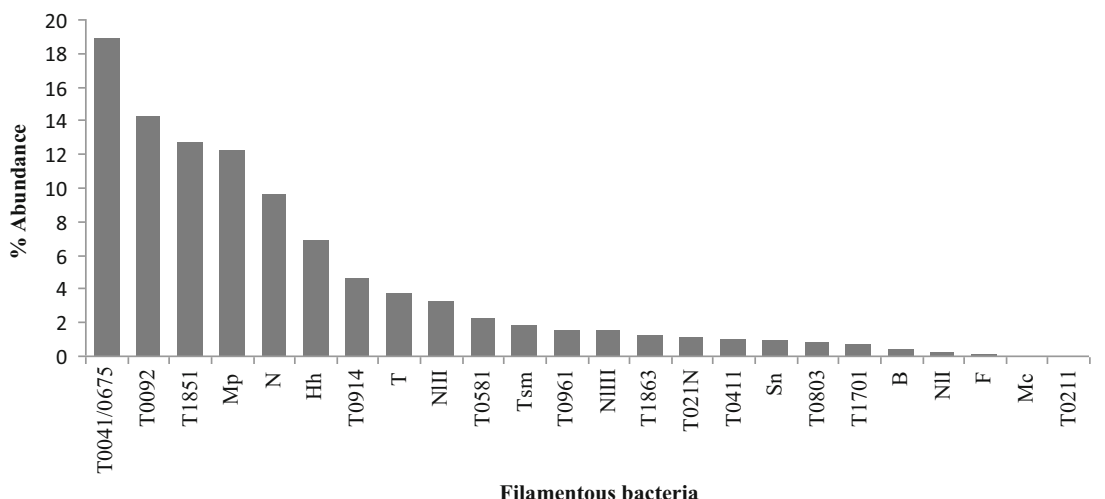

Fig. 2 Weighed abundance of filamentous bacteria in the studied WWTP. Type 0041/0675 (T0041/0675); type 0092 (T0092); Microthrix parvicella (Mp); type 1851 (T1851); nocardioforms (N); Haliscomenobacter hydrossis (Hh); Thiothrix spp. (T); Nostocoida limicola II (N1II); type 0914 (T0914); Nostocoida limicola III (N1III);

the highest number of correlations: with the affluent, mixed liquor and effluent $\mathrm{pH}$, the SRT, the $\mathrm{F} / \mathrm{M}$ (being this the only positive correlation with nocardioforms), and the nitrates in the effluent. M. parvicella positively correlated with four effluent parameters ( $\mathrm{pH}, \mathrm{CBO}$, total nitrogen, and ammonium) and with the mixed liquor $\mathrm{pH}$. Types 0092 and 1851 showed significant correlations with four environmental parameters, and $H$. hydrossis exhibited only two negative associations: with TSS and total nitrogen in sewage.

Table 6 shows the associations obtained by PCA between the filamentous bacteria species and some of the environmental parameters from the activated sludge in the 16 WWTP. Nine factors were extracted through factor analysis, explaining $73,636 \%$ of the total variance. In order to make each factor effective, the percentile explained by variance should be more than $10 \%$. In this case, only three factors were effectives. Due to the low percentage of explained variables, the three factors defined account for $39,482 \%$ of accumulated variances. The others factors might be useful through relating with correlation coefficients (Table 5). The factor loadings,

Table 3 Dominance of filamentous bacteria in the studied municipal WWTP

\begin{tabular}{ll}
\hline Dominant filamentous bacteria morphotype & Samples (\%) \\
\hline Type 1851 & 13 \\
Microthrix parvicella & 10 \\
Type $0041 / 0675$ & 9 \\
Type 0092 & 9 \\
Thiothrix similar morphology & 4 \\
Type 0581 & 3 \\
Type 0914 & 2 \\
Nocardioforms & 2 \\
Type $021 \mathrm{~N}$ & 1 \\
Sphaerotilus natans & 1 \\
\hline
\end{tabular}

type 0961 (T0961); type $021 \mathrm{~N}$ (T021N); type 1863 (T1863); type 0411 (T0411); type 0581 (T0581); Sphaerotilus natans (Sn); type 0803 (T0803); Beggiatoa spp. (B); Thiothrix-similar morphology (Tsm); type 1701 (T1701); Flexibacter (F); Nostocoida limicola I (NII); Microthrix calida (Mc).; type 0211 (T0211)

also called component loadings in PCA, are the correlation coefficients between the variables (biological and environmental parameters) and factors. The significant values for these factor loadings are above 0.60 according to Hair et al. (1995). Figure 3 shows the scatter diagrams of the first three and the fifth factors. The first principal component (factor 1) explains $16,017 \%$ of the total variance. This factor is related with organic matter (COD, BOD, and TSS) in plant affluent, and they are correlated positively with each other. The second factor, accounting for $12,446 \%$ of the total variance, is related with total phosphorous in sewage and dissolved oxygen in the aeration tank. The third factor, explaining $11,018 \%$ of the total variance, is also organic matter (COD, BOD, and TSS) but in this case, in the final effluent. The biological data, such as type $0041 / 0675$, type 1851 , and $H$. hydrossis are positively correlated and they constitute the fourth factor. The others factors are more related with environmental parameters, with the exception of the fifth factor, accounting with $6,619 \%$ of the total variance, showing that type 0092 had a relation with sludge volume index.

Table 4 Dominant filamentous bacteria in samples with $\mathrm{SVI} \geq 150 \mathrm{mg} / \mathrm{l}$

\begin{tabular}{ll}
\hline Filamentous bacteria & Samples (\%) \\
\hline Type 1851 & 16 \\
Microthrix parvicella & 13 \\
Type 0092 & 11 \\
Type $0041 / 0675$ & 8 \\
Thiothrix similar morphology & 5 \\
Type 0581 & 4 \\
Type 0914 & 2 \\
Nocardioforms & 2 \\
Type $021 \mathrm{~N}$ & 1 \\
Sphaerotilus natans & 1 \\
\hline
\end{tabular}


Table 5 Correlations between the filamentous bacteria and the environmental parameters (Kendall correlations)

\begin{tabular}{|c|c|c|c|c|c|c|}
\hline & Type 0041/0675 & Type 0092 & Type 1851 & Nocardioforms & Microthrix parvicella & Haliscomenobacter hydrossis \\
\hline \multicolumn{7}{|l|}{ Affluent } \\
\hline $\mathrm{pH}$ & -0.019 & $0.165^{*}$ & -0.040 & $-0.190^{*}$ & 0.074 & -0.055 \\
\hline $\mathrm{COD}(\mathrm{mg} / \mathrm{l})$ & -0.040 & -0.090 & -0.010 & 0.067 & -0.112 & -0.071 \\
\hline BOD (mg/l) & -0.063 & -0.042 & -0.004 & 0.104 & -0.122 & -0.057 \\
\hline TSS (mg/l) & -0.112 & -0.054 & -0.109 & 0.003 & 0.032 & -0.089 \\
\hline $\mathrm{TP}(\mathrm{mg} / \mathrm{l})$ & 0.114 & -0.138 & 0.060 & 0.055 & -0.029 & 0.026 \\
\hline $\mathrm{TN}(\mathrm{mg} / \mathrm{l})$ & 0.020 & -0.037 & $-0.155^{*}$ & -0.015 & -0.003 & $-0.159^{*}$ \\
\hline $\mathrm{NH}_{4}-\mathrm{N}(\mathrm{mg} / \mathrm{l})$ & -0.048 & 0.028 & $-0.176^{*}$ & -0.108 & -0.001 & -0.143 \\
\hline \multicolumn{7}{|l|}{ Areation tank } \\
\hline $\mathrm{pH}$ & -0.011 & 0.131 & -0.085 & $-0.193^{*}$ & $0.176^{*}$ & 0.078 \\
\hline SVI (ml/g) & 0.114 & $0.245^{* *}$ & $0.178^{*}$ & 0.069 & 0.021 & -0.078 \\
\hline SRT (days) & -0.035 & 0.122 & 0.120 & $-0.208^{* *}$ & -0.145 & 0.023 \\
\hline $\mathrm{F} / \mathrm{M}(\mathrm{kg} \mathrm{BOD} / \mathrm{kg}$ VSS.d) & -0.021 & $-0.232 * *$ & 0.020 & $0.288 * * *$ & 0.014 & 0.035 \\
\hline $\mathrm{DO}(\mathrm{mg} / \mathrm{l})$ & 0.030 & 0.006 & -0.018 & 0.075 & 0.056 & -0.033 \\
\hline TSS (mg/l) & -0.047 & 0.015 & -0.013 & 0.049 & 0.056 & $-0.176^{*}$ \\
\hline \multicolumn{7}{|l|}{ Final effluent } \\
\hline $\mathrm{pH}$ & -0.045 & $0.277 * * *$ & -0.121 & $-0.176^{*}$ & $0.176^{*}$ & 0.117 \\
\hline $\mathrm{COD}(\mathrm{mg} / \mathrm{l})$ & -0.029 & -0.070 & -0.085 & -0.024 & 0.044 & 0.096 \\
\hline BOD (mg/l) & -0.008 & 0.056 & 0.038 & 0.015 & $0.215^{* *}$ & 0.074 \\
\hline TSS (mg/l) & 0.026 & -0.028 & -0.091 & -0.002 & 0.124 & 0.032 \\
\hline $\mathrm{TP}(\mathrm{mg} / \mathrm{l})$ & 0.034 & 0.091 & -0.105 & -0.142 & -0.033 & 0.091 \\
\hline $\mathrm{TN}(\mathrm{mg} / \mathrm{l})$ & 0.119 & 0.107 & -0.141 & -0.120 & $0.168^{*}$ & -0.002 \\
\hline $\mathrm{NH}_{4}-\mathrm{N}(\mathrm{mg} / \mathrm{l})$ & 0.115 & 0.050 & -0.111 & -0.052 & $0.321 * * *$ & 0.062 \\
\hline $\mathrm{NO}_{3}-\mathrm{N}(\mathrm{mg} / \mathrm{l})$ & -0.064 & 0.116 & $-0.220^{* *}$ & $-0.158^{*}$ & -0.107 & -0.112 \\
\hline
\end{tabular}

$* P<0.05 ; * * P<0.01 ; * * * P<0.001$

\section{Discussion}

Types $0041 / 0675$ and 0092 , M. parvicella, and type 1851 were clearly the most frequent, abundant, and dominant morphotypes in these 16 WWTP, despite the fact that type 1851 was clearly the most dominant and the fourth in frequency and abundance. On the other hand, types 0041/0674 and 0092 were the most frequent and abundant but stood after type 1851 and M. parvicella when considering dominance.

High frequencies of M. parvicella and type 0041/0675 were observed by Blackbeard et al. (1988), Bux and Kasan (1994), and Lacko et al. (1999) that accredit success of these organisms to their ability to survive and to adapt to wide parameter ranges usual in activated sludge systems. Eikelboom et al. (1998) state that M. parvicella was clearly the most important filamentous species in nutrient removal plants, and Madoni et al. (2000) also observed that this species was the most frequent in foaming and bulking situations. In the present case, however, that was not observed: $M$. parvicella was the second in dominance but only the fourth in frequency and abundance. The importance of the type 0092 was not surprising as this is a frequent morphotype in nutrient removal plants.
In the set of morphotypes with frequencies higher than $50 \%$, two were not among the most dominants: H. hydrossis and nocardioforms. H. hydrossis was a frequent and abundant filament that did not reach dominant positions in activated sludge. It is to remember, however, that confirmations only took in consideration those filaments that hybridized with the probe $\mathrm{HHY}$ and other $H$. hydrossis-like filaments hybridize with other probes (Kragelund et al. 2008). Nocardioforms, on the other hand, were the fifth in the rank of the most frequent and abundant but were dominant in only $2 \%$ of the WWTP and in $2 \%$ of the bulking systems. The relatively low importance of nocardioforms was not expected (Eikelboom 1975; Jenkins et al. 1993; Rampersad 2002) but the fact that the samples of the present study were all coming from nutrient removal plants can account for the fact.

Seviour and Nielsen (2010) reported that the most abundant filaments in nutrient-removal WWTP treating mainly municipal wastewater were $M$. parvicella; followed by types 0041/0675, 1851, and 1701; type 0041 in TM7 division; H. hydrossis; nocardioforms; type 0092; and type 0803. In what abundance concerns, the present results do not confirm these findings. 
Table 6 Factor analysis of the filamentous bacteria and the environmental parameters

\begin{tabular}{|c|c|c|c|c|c|c|c|c|c|c|}
\hline & & Factor 1 & Factor 2 & Factor 3 & Factor 4 & Factor 5 & Factor 6 & Factor 7 & Factor 8 & Factor 9 \\
\hline & Type $0041 / 0675$ & -0.042 & 0.112 & -0.117 & $0.772^{*}$ & 0.006 & 0.204 & -0.033 & 0.023 & 0.061 \\
\hline & Type 0092 & -0.101 & -0.274 & 0.013 & 0.058 & $-0.731^{*}$ & 0.182 & 0.262 & -0.010 & -0.112 \\
\hline & Type 1851 & -0.057 & 0.081 & -0.027 & $0.614^{*}$ & -0.316 & -0.357 & -0.129 & 0.053 & -0.102 \\
\hline & Nocardioforms & 0.171 & 0.159 & -0.125 & 0.557 & 0.058 & -0.191 & -0.201 & 0.126 & 0.423 \\
\hline & Microthrix parvicella & -0.156 & 0.010 & 0.249 & 0.047 & -0.321 & 0.030 & 0.461 & 0.251 & 0.385 \\
\hline & Haliscomenobacter hydrossis & -0.061 & -0.180 & 0.238 & $0.700^{*}$ & 0.073 & -0.039 & 0.242 & -0.348 & -0.113 \\
\hline Affluent & $\mathrm{pH}$ & 0.198 & 0.294 & 0.075 & -0.204 & -0.489 & 0.198 & 0.406 & -0.047 & -0.307 \\
\hline & $\mathrm{COD}(\mathrm{mg} / \mathrm{l})$ & $0.912 *$ & -0.010 & 0.161 & 0.019 & -0.008 & 0.078 & -0.064 & 0.018 & 0.025 \\
\hline & $\mathrm{BOD}(\mathrm{mg} / \mathrm{l})$ & $0.951^{*}$ & -0.014 & 0.043 & 0.041 & -0.007 & -0.034 & -0.065 & 0.022 & 0.022 \\
\hline & $\mathrm{TSS}(\mathrm{mg} / \mathrm{l})$ & $0.872 *$ & -0.073 & 0.136 & -0.073 & 0.039 & 0.159 & 0.017 & 0.078 & 0.127 \\
\hline & $\mathrm{TP}(\mathrm{mg} / \mathrm{l})$ & 0.101 & $0.749^{*}$ & 0.091 & 0.206 & 0.119 & -0.079 & -0.207 & -0.086 & -0.022 \\
\hline & $\mathrm{TN}(\mathrm{mg} / \mathrm{l})$ & 0.579 & 0.119 & -0.291 & -0.104 & 0.083 & 0.424 & 0.114 & 0.186 & -0.125 \\
\hline & $\mathrm{NH}_{4}-\mathrm{N}(\mathrm{mg} / \mathrm{l})$ & 0.368 & -0.463 & -0.162 & -0.206 & 0.034 & 0.462 & 0.185 & 0.356 & -0.143 \\
\hline Areation tank & $\mathrm{pH}$ & -0.142 & 0.065 & 0.022 & -0.072 & 0.054 & -0.135 & $0.824^{*}$ & -0.173 & -0.053 \\
\hline & $\mathrm{DO}(\mathrm{mg} / \mathrm{l})$ & -0.135 & $0.683^{*}$ & 0.136 & -0.086 & -0.185 & 0.132 & 0.197 & -0.044 & 0.120 \\
\hline & TSS (mg/l) & 0.188 & -0.182 & 0.178 & -0.059 & 0.042 & -0.134 & -0.121 & $0.765^{*}$ & -0.016 \\
\hline & SVI (ml/g) & 0.001 & 0.201 & -0.123 & 0.061 & $-0.821^{*}$ & -0.149 & -0.190 & -0.040 & -0.022 \\
\hline & SRT (days) & -0.051 & -0.034 & -0.095 & 0.018 & -0.100 & 0.018 & 0.080 & 0.015 & $-0.831^{*}$ \\
\hline & $\mathrm{F} / \mathrm{M}\left(\mathrm{kg} \mathrm{BOD}_{5} / \mathrm{kg}\right.$ VSS.d) & 0.348 & 0.188 & 0.331 & 0.067 & 0.216 & -0.214 & 0.026 & -0.383 & 0.498 \\
\hline Effluent & $\mathrm{pH}$ & 0.106 & -0.193 & -0.042 & -0.011 & -0.086 & 0.168 & 0.815 & -0.001 & -0.113 \\
\hline & $\mathrm{COD}(\mathrm{mg} / \mathrm{l})$ & 0.225 & 0.148 & $0.760^{*}$ & -0.047 & 0.068 & 0.097 & -0.017 & 0.036 & -0.090 \\
\hline & $\mathrm{BOD}(\mathrm{mg} / \mathrm{l})$ & 0.090 & 0.099 & $0.786^{*}$ & 0.120 & -0.043 & 0.024 & 0.099 & 0.169 & 0.116 \\
\hline & $\mathrm{TSS}(\mathrm{mg} / \mathrm{l})$ & -0.055 & -0.005 & $0.815^{*}$ & -0.139 & 0.045 & 0.086 & 0.025 & -0.027 & 0.136 \\
\hline & $\mathrm{TP}(\mathrm{mg} / \mathrm{l})$ & 0.213 & -0.088 & 0.155 & 0.092 & 0.057 & $0.739^{*}$ & 0.006 & -0.056 & -0.174 \\
\hline & $\mathrm{TN}(\mathrm{mg} / \mathrm{l})$ & -0.006 & 0.166 & 0.216 & 0.045 & -0.036 & $0.719^{*}$ & 0.332 & 0.203 & 0.011 \\
\hline & $\mathrm{NH}_{4}-\mathrm{N}(\mathrm{mg} / \mathrm{l})$ & 0.022 & 0.169 & 0.273 & 0.106 & 0.117 & 0.392 & 0.517 & 0.424 & 0.099 \\
\hline & $\mathrm{NO}_{3}-\mathrm{N}(\mathrm{mg} / \mathrm{l})$ & 0.065 & -0.026 & -0.063 & -0.214 & -0.177 & 0.773 & -0.210 & -0.341 & 0.075 \\
\hline Variance expla & ned $(\%)$ & 16.017 & 12.446 & 11.018 & 7.504 & 6.619 & 5.993 & 5.274 & 4.598 & 4.166 \\
\hline Accumulated & ariance $(\%)$ & 16.017 & 28.464 & 39.482 & 46.985 & 53.605 & 59.598 & 64.872 & 69.470 & 73.636 \\
\hline
\end{tabular}

* statistical significant

The fact that 97 of the 128 samples correspond to bulking situations can account for the coincidence of dominance in the total of samples and in bulking samples. But it can be said that in these 128 samples from 16 nutrient-removal plants, type 1851 was the main responsible of bulking, closely followed by M. parvicella, type 0092, and type 0041/0675.

Concerning the relations found between the filamentous morphotypes and the physical-chemical and operation parameters, no associations were found between type 0041/0675 and the environmental parameters corroborating Blackbeard et al. (1988); Bux and Kasan (1994) and Lacko et al. (1999) that stated its ability to survive and adapt to wide parameter ranges usual in activated sludge systems.

Since type 0092 showed a positive correlation with $\mathrm{pH}$ (in both influent and final effluent) and SVI and a negative correlation with organic load and, this filamentous bacteria can be a useful indicator of low sedimentation proprieties, low organic load, and relatively high $\mathrm{pH}$ in the plant. Madoni et al. (2000) also reported that type 0092 was dominant only in plants with low F/M load. Eikelboom (2000) stated that this morphotype is largely present inside the flocs with limited effect on the SVI, but Blackbeard et al. (1986) observed these filamentous bacteria as dominant in bulking and foaming activated sludge plants. The present results corroborate the latter. Many authors observed that type 0092 appears in many filament bacteria surveys carried out on plants around the world (Martins et al. 2004; Tandoi et al. 2006), and it has been associated with long sludge age. This association was not observed in this study. This filament morphotype was classified as an "all-zone" grower by Wanner and Grau (1989), able to grow under aerobic, anoxic, and anaerobic conditions, and this can be the reason for not founding any correlation with dissolved oxygen.

Type 1851 was also positively correlated with SVI and, as type 0092, can be a good indicator of bad sedimentation of the 

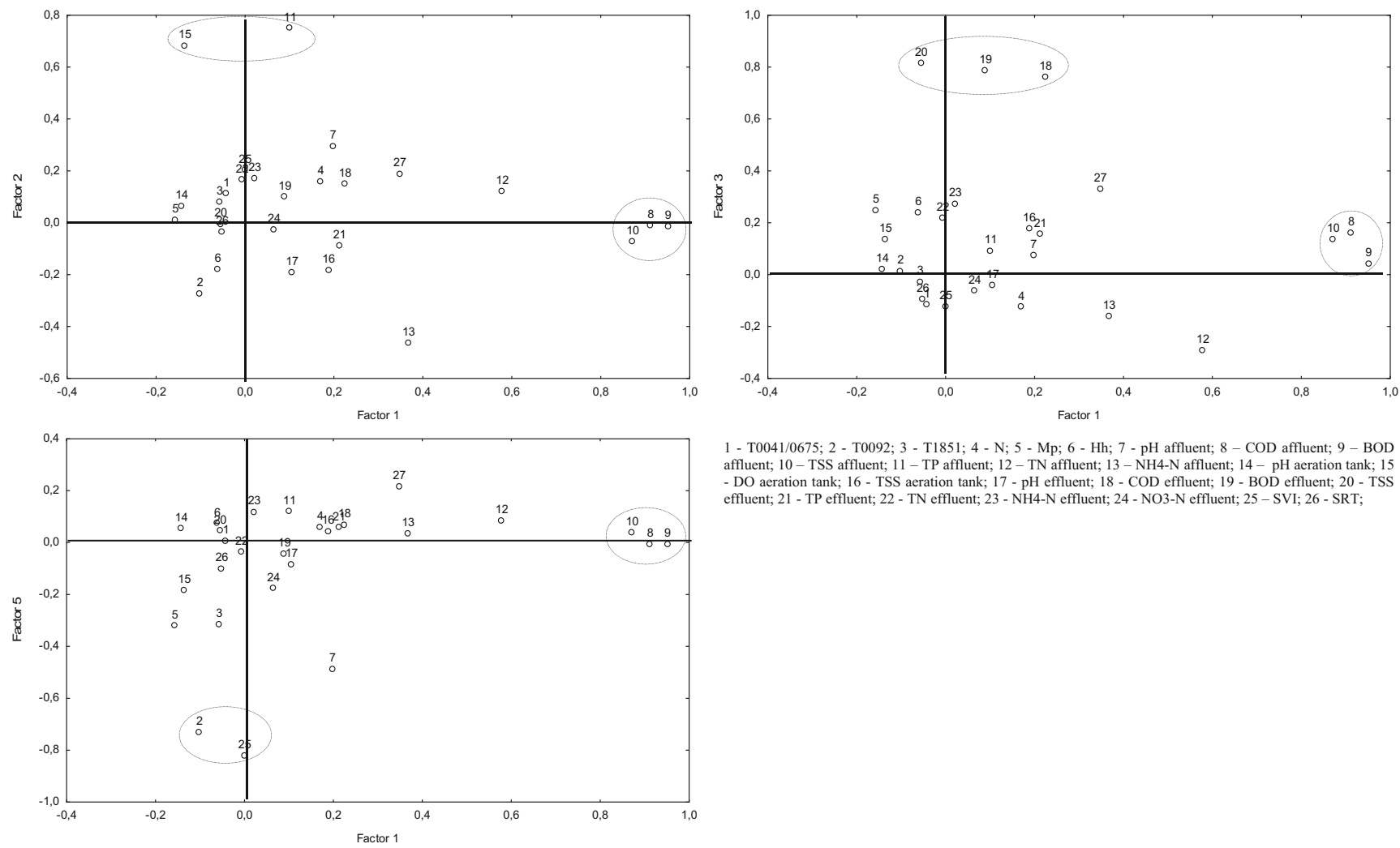

1 - T0041/0675; 2 - T0092; 3 - T1851; 4 - N; 5 - Mp; 6 - Hh; 7 - pH affluent; 8 - COD affluent; 9 - BOD affluent; 10 - TSS affluent; 11 - TP affluent; 12 - TN affluent; $13-\mathrm{NH} 4-\mathrm{N}$ affluent; $14-\mathrm{pH}$ aeration tank; 15 - DO aeration tank; 16 - TSS aeration tank; 17 - pH effluent; 18 - COD effluent; 19 - BOD effluent; 20 - TSS
effluent; 21 - TP effluent; 22 - TN effluent; 23 - NH4-N effluent; 24 - NO3-N effluent; 25 - SVI; 26 - SRT;

Fig. 3 Distribution of the filamentous bacteria and environmental parameters as defined by the first three factors of the principal component analysis. Type 0041/0675 (T0041/0675); type 0092

(T0092); Microthrix parvicella (Mp); type 1851 (T1851); nocardioforms (N); Haliscomenobacter hydrossis $(\mathrm{Hh})$

sludge. This filament was dominant in urban plants receiving domestic and mixed sewage, contradicting several authors that referred its dominance in industrial but not in domestic plants (Eikelboom 2000; Seviour and Blackall 1999), namely in the presence of simple sugars and soluble starches (Jenkins et al. 2004). The negative correlation with sewage, $\mathrm{TN}$, and $\mathrm{NH}_{4}-\mathrm{N}$ and effluent $\mathrm{NO}_{3}-\mathrm{N}$, suggests that type 1851 is associated with nitrogen deficiencies, although these associations were never reported in previous studies.

Nocardioforms were positively associated with $\mathrm{F} / \mathrm{M}$, supporting others works that found nocardioforms at broad organic load levels (Jenkins et al. 1993; Madoni et al. 2000). Consequently, they were negatively correlated with sludge age (SRT). Also, nocardioforms increased when the $\mathrm{pH}$ in the plant decreased. Madoni et al. (2005) reported that the optimum $\mathrm{pH}$ for nocardioforms is between 7 and 8 , and their growth rate decreases and attains a minimum at $\mathrm{pH} 5$, contradicting the results of the present study. In contrast, Spigoni et al. (1992) described that Nocardia spp. is favored by relatively low $\mathrm{pH}$ (6.5-7.1). As the studied plants are all nutrient-removal WWTP, the negative correlation with the final effluent nitrate level, also observed with the type 1851 , can mean that these two morphotypes are associated with good denitrifying conditions.

M. parvicella was positively correlated with the $\mathrm{pH}$ in the aeration tank and in the final effluent. Spigoni et al. (1992)

stated that M. parvicella in pure culture has a $\mathrm{pH}$ optimum between 7 and 8 , while in the activated sludge is also found at lower $\mathrm{pH}$, controverting the association found in this study. Positive correlations were also found between this filament and BOD, TN, and $\mathrm{NH}_{4}-\mathrm{N}$ in the final effluent. This can simply means that $M$. parvicella in higher abundances causes the washout of biomass explaining the higher content of nitrogen and organic matter in the effluent.

Finally, the negative correlation between $H$. hydrossis with nitrogen in the influent was not expected since these filamentous bacteria are associated with high concentration of nitrogen compounds (Eikelboom 2000; Madoni et al. 2000). The negative correlation with TSS is not mentioned in other works. It was predictable that $H$. hydrossis should show a negative association with oxygen in aeration tank (Seviour and Blackall 1999; Jenkins et al. 1993; Wanner and Grau 1989), but no associations were found in the present study.

From PCA it can be seen that the organic matter-related variables (COD, BOD, and TSS) in plant influent and in the final effluent are correlated with each other, which is expectable. Biological data, such as the abundances of type $0041 / 0675$, type 1851 , and $H$. hydrossis, are positively associated with each other, meaning that they are expected to appear together. Eikelboom (2000) described that H. hydrossis and type 0041/0675 populations are always small 
in domestic WWTP with nutrient removal, so they can appear together. The presence of both H. hydrossis and type 1851 was also detected in an influent from agro-industry (Eikelboom 2000). Although, H. hydrossis are present in high F/M and types $0041 / 0675$ and 1851 are present in low F/M, so there is not a condition that all have in common, which contradicts the results of PCA. The only significant PCA association between biologic and environmental parameters is the association between type 0092 and SVI, corroborating the correlation found in Kendall correlation analysis. PCA can be a useful method for reducing the number of variables to be taken in account in a data set by finding linear combinations of those variables that explain most of the variability. In the present case, PCA was of limited value but presented some expected associations among some environmental parameters (COD, BOD, and TSS in entrance and exit) and among some of the filamentous morphotypes. It also reaffirmed the association between type 0092 and SVI.

The results of the present study, including the different ranges of the various morphotypes when considering frequency, abundance, and dominance, and the contradictions among results published by other authors, emphasize the importance of distinguishing between frequency, abundance, and dominance of filamentous morphotypes in domestic and industrial WWTP, including the correlations with environmental parameters.

Acknowledgments This study was supported by the Portuguese Foundation for Science and Technology (FCT) and the European Community fund FEDER, through Program COMPETE, in the ambit of the Projects FCOMP-01-0124-FEDER-007025 (PTDC/AMB/68393/2006), PEstOE/EQB/LA0023/2013, RECI/BBB-EBI/0179/2012 (FCOMP-010124-FEDER-027462), and the Project "BioEnv - Biotechnology and Bioengineering for a sustainable world," REF. NORTE-07-0124FEDER-000048, co-funded by the Programa Operacional Regional do Norte (ON.2 - O Novo Norte), QREN, FEDER. The authors also thank the $\mathrm{PhD}$ grant SFRH/BD/64848/2009 attributed to Liliana Santos.

\section{References}

Amann RI, Krumholz L, Stahl DA (1990) Fluorescent-oligonucleotide probing of whole cells for determinative, phylogenetic, and environmental studies in microbiology. J Bacteriol 172:762-770

APHA/AWWA/WEF (1995) Standard methods for the evaluation of water and wastewater, 19th edn. APHA, Washington

Beer M, Seviour EM, Kong Y, Cunningham M, Blackall LL, Seviour RJ (2002) Phylogeny of the filamentous bacterium Eikelboom type 1851, and design and application of a 16S rRNA targeted oligonucleotide probe for its fluorescence in situ identification in activated sludge. FEMS Microbiol Lett 207:179-183

Bjornsson L, Hugenholtz P, Tyson GW, Blackall LL (2002) Filamentous Chloroflexi (green non-sulfur bacteria) are abundant in wastewater treatment processes with biological nutrient removal. Microbiology 148:2309-2318
Blackbeard JR, Ekama GA, Marais GVR (1986) A survey of bulking and foaming activated sludge plants in South Africa. J Water Pollut Control Fed 85:90-100

Blackbeard JR, Gabb D, Ekama GA, Marais GR (1988) A survey of filamentous bulking and foaming in activated sludge plants in South Africa. Water SA 14:29-33

Bux F, Kasan HC (1994) A microbiological survey of ten activated sludge plants. Water SA 20:61-71

Daims H, Bruhl A, Amann R, Schleifer KH, Wagner M (1999) The domain-specific probe EUB338 is insufficient for the detection of all bacteria: development and evaluation of a more comprehensive probe set. Syst Appl Microbiol 22:434-444

Davenport RJ, Curtis TP, Goodfellow M, Stainsby FM, Bingley M (2000) Quantitative use of fluorescent in situ hybridization to examine relationships between mycolic acid-containing actinomycetes and foaming in activated sludge plants. Appl Environ Microbiol 66: $1158-1166$

Eikelboom DH (1975) Filamentous organisms observed in activated sludge. Water Res 9:365-388

Eikelboom DH (2000) Process control of activated sludge plants by microscopic investigation. IWA Publishing, London, UK

Eikelboom DH, Andreadakis A, Andreasen K (1998) Survey of filamentous populationsin nutrient removal plants in four European countries. Water Sci Technol 37:281-289

Erhart R, Bradford D, Seviour RJ, Amann R, Blackall LL (1997) Development and use of fluorescent in situ hybridization probes for the detection and identification of Microthrix parvicella in activated sludge. Syst Appl Microbiol 20:310-318

Gich F, Garcia-Gil J, Overmann J (2001) Previously unknown and phylogenetically diverse members of the green nonsulfur bacteria are indigenous to freshwater lakes. Arch Microbiol 177:1-10

Hair JF, Anderson RE, Tatham RL, Black WC (1995) Multivariate data analysis. Prentice Hall, Englewood Cliffs, NJ

Jenkins D, Richard MG, Daigger GT (1993) Manual on the causes and control of activated sludge bulking and foaming, 2nd edn. Lewis Publishers, Michigan, USA

Jenkins D, Richard MG, Daigger GT (2004) Manual on the causes and control of activated sludge bulking, foaming, and other solids separation problems, 3rd edn. Lewis Publisher, NY, USA

Kanagawa T, Kamagata Y, Shinobu A, Tetsuro K, Horn M, Wagner M (2000) Phylogenetic analysis and oligonucleotide probe development for the eikelboom type $021 \mathrm{~N}$ filamentous bacteria isolated from bulking activated sludge. Appl Environ Microbiol 66:50435052

Kragelund C, Levantesi C, Borger A, Thelen K, Eikelboom D, Tandoi V, Kong Y, Krooneman J, Larsen P, Thomsen TR, Nielsen PH (2008) Identity, abundance and ecophysiology of filamentous bacteria belonging to the bacteroidetes present in activated sludge plants. Microbiol 154:886-894

Lacko N, Bux F, Kasan HC (1999) Survey of filamentous bacteria in activated sludge plants in KwaZulu-Natal. Water SA 25:63-68

Madoni P, Davoli D, Gibin G (2000) Survey of filamentous microorganisms from bulking and foaming activated-sludge plants in Italy. Water Res 34:1767-1772

Madoni P, Davoli C, Davoli D, Guglielmi L, Pergetti M, Stefanini C (2005) Depurazione biologica nei fanghi attivi. Universita degli Studi di Parma; Enia S.p.A. - Sede di Reggio Emilia, Italia

Martins A, Pagilla K, Heijnen J, van Loosdrecht M (2004) Filamentous bulking sludge: a critical review. Water Res 38:793-817

Müller E, Schade M, Lemmer H (2007) Filamentous scum bacteria in activated sludge plants: detection and identification quality by conventional activated sludge microscopy versus fluorescence in situ hybridization. Water Environ Res 79:2274-2286

Nielsen PH, Daims H, Lemmer H (2009) FISH handbook for biological wastewater treatment. IWA Publishing, London, UK 
Rampersad K (2002) Survey of filamentous bacteria in activated sludge plants and the effect of seasonal variations. Biennial Conference of the Water Institute of Southern Africa (WISA) 19 - 23 May, Durban

Seviour RJ, Blackall LL (1999) The microbiology of activated sludge. Kluwer Academic Publishers, Dordrecht, Netherlands

Seviour R, Nielsen PH (2010) Microbial ecology of activated sludge. IWA Publishing, London, UK

Speirs L, Nittami T, McIlroy S, Schroeder S, Seviour RJ (2009) Filamentous bacterium Eikelboom type 0092 in activated sludge plants in Australia is a member of the phylum Chloroflexi. Appl Environ Microbiol 75:2446-2452

Spigoni G, Davoli C, Davoli D (1992) I principali microrganismi filamentosi del fango attivo: caratteristiche ecologiche e metodi di identificazione. Quaderni tecnici dell'AGAC, n5
Tandoi V, Jenkins D, Wanner J (2006) Activated sludge separation problems. IWA Publishing, London, UK

Wagner M, Erhart R, Manz W, Amann RI, Lemmer H, Wedi D, Schleifer KH (1994) Development of an R-RNA-targeted oligonucleotide probe specific for the genus acinetobacter and its application for in situ monitoring in activated sludge. Appl Environ Microbiol 60: $792-800$

Wallner G, Amann R, Beisker W (1993) Optimizing fluorescent in situ hybridization with rRNA-targeted oligonucleotide probes for flow cytometric identification of microorganisms. Cytometry 14:136143

Wanner J, Grau P (1989) Identification of filamentous microorganisms from activated sludge: a compromise between wishes, needs and possibilities. Water Res 23:883-891 